\title{
To the taxonomy of the genus Scathophaga Meigen, 1803 (Diptera: Scathophagidae) with description of a new species
}

\author{
К таксономии двукрылых рода Scatbophaga Meigen, 1803 \\ (Diptera: Scathophagidae) с описанием нового вида
}

\author{
A.L. Ozerov ${ }^{1,3}$, M.G. Krivosheina ${ }^{2}$

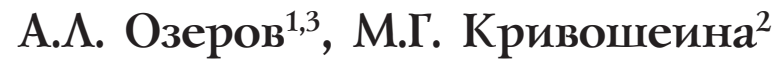

\begin{abstract}
${ }^{1}$ Zoological Museum, Moscow Lomonosov State University, Bol'shaya Nikitskaya 2, Moscow 125009, Russia. E-mail: ozerov2455@rambler.ru

Зоологический музей, Московский государственный университет им. М.В. Ломоносова, Большая Никитская ул., 2, Москва 125009, Россия

${ }^{2}$ A.N. Severtsov Institute of Ecology and Evolution, Russian Academy of Sciences, Leninsky prospect, 33, Moscow 119071, Russia. Email: dipteramarina@rambler.ru

${ }^{2}$ Институт проблем экологии и эволюции им. А.Н. Северцова РАН, Ленинский проспект, 33, Москва 119071, Россия.

${ }^{3}$ corresponding author
\end{abstract}

KEY WORDS: Diptera, Scathophagidae, Scathophaga, new species, new synonym, Azerbaijan, Russia. Россия.

КЛЮЧЕВЫЕ СЛОВА: Diptera, Scathophagidae, Scathophaga, новый вид, новый синоним, Азербайджан,

ABSTRACT. One species, Scathophaga incompleta sp.n. (Diptera: Scathophagidae), is described as new to science. One new synonym is proposed: Scathophaga decipiens (Haliday in Curtis, 1832) = Scathophaga fluvialis (Rondani, 1867), syn.n.

РЕЗЮМЕ. Приводится описание одного нового для науки вида - Scathophaga incompleta sp.n. (Diptera: Scathophagidae). Установлен один новый синоним: Scathophaga decipiens (Haliday in Curtis, 1892) = Scathophaga fluvialis (Rondani, 1867), syn.n.

\section{Introduction}

During the determination of the material on Scathophagid flies of the genus Scathophaga Meigen, 1803 kept in the Zoological Museum of the Moscow Lomonosov State University (ZMUM) we discovered two close species, which were determined firstly as $S$. decipiens (Haliday in Curtis, 1832) and S. fluvialis (Rondani, 1867). The original description of $S$. decipiens (as Scatophaga decipiens) is quite short and it is impossible to determine the species from it unambiguoosly [Curtis, 1832]. Other descriptions are absent. The original description of S. fluvialis (as Scatina fluvialis) is very short too [Rondani, 1967]. However Šifner [1969] gave more detalied and complete description of this species and made figures of male abdominal sternite 5 and male genitalia.
We decided to examine both species and loaned them from Museo di Storia Naturale dell'Universita Sezione di Zoologia La Specola, Firenze, Italia (MZLS) and Oxford University Museum of Natural History, Oxford, United Kindom (UMO). We also asked for the information about the type specimen of S. decipiens from Melbourne Museum (formerly: National Museum of Victoria), Melbourne, Australia (NMV).

\section{Materail and methods}

We got the next material: syntype male of $S$. fluvialis labelled "1439", "Museo la "Specola" / coll. Rondani / SYNTYPUS" (MZLS), syntype male of S. fluvialis labeled "Syntype", "type", "S. fluvialis / ex. coll. Big.", "Syntype O' / Scatina / fluvialis / Rondani, 1867 / Conf. A.C. Pont, 2014" (UMO), and 3 males of $S$. decipiens labelled "Nflk [Norfolk] / Morston / 10.X.51", "Ex V-C Duplicates / Standing over / Scatophaga / dalmatica / Becker, 1984" (UMO). Genitalia of both syntypes of $S$. fluvialis and of one specimen of $S$. decipiens were studied.

Besides the photo of the syntype of $S$. decipiens from NMV was got ( $O^{7}$ with label as in Fig. 1: 28 May / Tolisby [north of England, county of Yorkshire]).

Dissected male genitalia were examined with a Nikon SMZ645 zoom stereomicroscope and then photographed using an eTREK DCM900 digital camera

How to cite this article: Ozerov A.L., Krivosheina M.G. 2020. To the taxonomy of the genus Scathophaga Meigen, 1803 (Diptera: Scathophagidae) with description of a new species // Russian Entomol. J. Vol.29. No.2. P.227-231. doi: 10.15298/rusentj.29.2.20 
attached in place of an eyepiece of monocular microscope. Resulting batches of images were processed with CombineZP software, editing of stacked images was performed in Adobe Photoshop.

\section{Results}

All the abovementioned specimens were examined and proved to be conspecific. So, the name Scatina fluvialis Rondani, 1867 is a new junior synonym of Scathophaga decipiens (Haliday in Curtis, 1832).

The next specimens from Russia kept in the collections of ZMUM and ZISP are identical to the $S$. decipiens: $5 \sigma^{7} \sigma^{7}, 3$ \% 3 , labelled "Crimea, Kerch env. $\left(45.2^{\circ} \mathrm{N}\right.$ 36. $\left.{ }^{\circ} \mathrm{E}\right), 26 . I V .2014$, N. Vikhrev” (ZMUM); 1 o', labelled "Crimea, Ai-Petri $\left(44.45^{\circ} \mathrm{N} 34.05^{\circ} \mathrm{E}\right), 1170 \mathrm{~m}$, 28.IX.2015, N. Vikhrev” (ZMUM); $1 \sigma^{\top}, 4$ oㅇ, labelled "Rostov Oblast, Kamensk-Shakhtinsky $\left(48.293^{\circ} \mathrm{N}\right.$ 40.257 ${ }^{\circ}$ E), 25.V.2011, D. Gavryushin" (ZMUM); $1 \mathrm{O}^{7}$, labelled "Crimea, Crimea Nature reserve $\left(44.689^{\circ} \mathrm{N}\right.$ 34.205 E), 1.IX.1929, Bukovsky" (ZISP); $1 \mathrm{O}^{\top}$, labelled "Crimea, Tarchankut env. $\left(45.350^{\circ} \mathrm{N} 32.496^{\circ} \mathrm{E}\right)$, 21.V.1913, Aleksandrov" (ZISP); and from Ukraine: 5 $\sigma^{7} \sigma^{7}, 2$ ơ, labelled "Odessa env. (ca. $46.498^{\circ} \mathrm{N}$ $\left.30.678^{\circ} \mathrm{E}\right), 16,23$ and 30.V.1926, L. Zimin” (ZISP).

We attributed a part of the specimens from Russia (Crimea as well as specimens collected in Kalmykia and Adygea) and from Azerbaijan (see below) to a new species. Its description is given below.

The morphological terminology used in the description follows McAlpine [1981], Cumming \& Wood [2009] and Stuckenberg [1999].

\section{Description of a new species}

\section{Scathophaga incompleta sp.n. Figs 8-13.}

MATERIAL. Holotype $\sigma^{7}$, Russia: Kalmykia, Priyutnoe env. (46.1 $\left.{ }^{\circ} \mathrm{N} 43.5^{\circ} \mathrm{E}\right), 2-3 . V .2013$, N. Vikhrev (ZMUM). Paratypes: same labels (9 $\sigma^{\top} \sigma^{7}, 9$ 90 , ZMUM); Russia: Crimea, Ai-Petri (44.45 $\left.{ }^{\circ} \mathrm{N} 34.05^{\circ} \mathrm{E}\right), 1170 \mathrm{~m}, 28 . \mathrm{IX} .2015$, N. Vikhrev (1 $\sigma^{\top}, \mathrm{ZMUM}$ ); Crimea, Kerch env. $\left(45.2^{\circ} \mathrm{N} 36.1^{\circ} \mathrm{E}\right), 26 . I V .2014$, N. Vikhrev (3 $\sigma^{7} \sigma^{7}$, ZMUM); Crimea, Crimea Nature reserve (ca. $44.666^{\circ} \mathrm{N}$ $\left.34.238^{\circ} \mathrm{E}\right)$, 24.VII.1936, V. Geptner (1 $\sigma^{7}$, ZISP); Crimea, Dzhankoy $\left(45.713^{\circ} \mathrm{N} 34.396^{\circ} \mathrm{E}\right), 19 . \mathrm{V} .1963$, Gorodkov (3 $\sigma^{7} \sigma^{7}$, ZMUM); Adygea, Lagonaki $\left(44.050^{\circ} \mathrm{N} 40.018^{\circ} \mathrm{E}\right), 1830 \mathrm{~m}, 20-23 . \mathrm{VI} .2009$, K. Tomkovich (1 $\sigma^{7}$, ZMUM); Azerbaijan: Ceyranbatan reservoir (ca. $\left.40.536^{\circ} \mathrm{N} 49.664^{\circ} \mathrm{E}\right), 17 . X .1985$, Nartshuk (2 $\sigma^{7} \sigma^{7}$, ZISP).

DESCRIPTION. Male, female. Length of body 5.8$6.6 \mathrm{~mm}$. Length of wing 5.6-7.0 $\mathrm{mm}$.

Head. Frontal vitta yellow, matt; fronto-orbital plate blackish, densely pale grey dusted, ocellar triangle blackish. Face and gena yellow, densely whitish dusted. Postcranium blackish, densely pale grey dusted. Setae: 2-3 orbitals, 2-4 frontals, 1 ocellar, 1 postocellar, 1 inner vertical, 1 outer vertical; 1 pair of strong vibrissae and 2 pairs of subvibrissae present. Postcranium covered with white hairs in lower half. Antenna black; postpedicel about twice as long as wide. Arista black, bare. Palpus yellow.
Thorax black, densely pale grey dusted; scutum with a double brownish line down the middle, and an obscure one on each side. Acrostichals in two rows, not differentiated from the other hairs on scutum, 2 postpronotals, 2 notopleurals, $1+2$ supra-alars, $1+(1-2)$ intra-alars (posterior postsutural intra-alar seta small, about 0.5 times as long as anterior one or absent) (Fig. 8), 2 postalars and $2+3$ dorsocentrals. Proepisternum centrally and ventrally with whitish hairs, without strong setae ventrally. Proepimeron with whitish hairs. Anepisternum covered with hairs completely and with 2-3 strong setae along posterior margin. Katepisternum covered with hairs completely, covered with long whitish hairs posteriorly and with one strong seta in posterodorsal corner. Postmetacoxal bridge absent. Scutellum greyish dusted, with a pair of strong basal scutellar and a pair of strong apical scutellar setae.

Legs. All coxae black, greyish dusted. All femora greyish dusted, black, except yellow apex: 1/4 in mid femur and 1/5-1/6 in fore and hind femora. All tibiae and tarsi yellow. Fore femur with whitish hairs, longer ventrally, with 4-5 dorsal setulae in apical third. Fore tibia with 2-3 dorsal, 3-4 posterodorsal, 1-2 posterior, 1 preapical posterodorsal, 1 apical posteroventral, 1 apical posterior setae. Mid femur with a row of anterodorsal setae, with 1 preapical posterodorsal and 1 preapical posterior setae. Mid tibia with 1-2 anterodorsal, 1-2 posterodorsal, 2 posterior (thin), 1 ventral (strong in female) setae, also with a ring of apicals. Hind femur with a row of dorsal/anterodorsal setae. Hind tibia with 2-3 posterodorsal, 2-3 anterodorsal, 1 preapical dorsal, 1 preapical anterodorsal and 1 apical anteroventral setae.

Wing clear, veins brownish. Vein $\mathrm{R}_{1}$ bare. Calypters, margins of calypters, and halteres yellowish.

Abdomen black, densely pale grey dusted, covered with whitish hairs. Tergites $2-5$ in male and tergiters 2-6 in female each with a row of marginal setae.

Male sternite 4 almost twice as long as wide (Fig. 9). Male sternite 5 with moderately long and narrow lobes, with a small projection medially between lobes (Fig. 10). Cercal plate longer than surstyli and narrowing to a slender incurved tip (Figs 12, 13). Aedeagus as in Fig. 11.

COMPARISON. The new species is similar to $S$. decipiens (Haliday) and S. obscura (Fallén, 1819) by the structure of cercal plate which is longer than surstylus and narrowing to a slender incurved tip.

In S. obscura intra-alar setae absent, often only one postrponotal seta present. Both the new species and $S$. decipiens have intra-alar setae and always with two postrponotal setae. The distinctions between $S$. incompleta and $S$. decipiens are the following: $S$. decipiens with two strong postsutural intraalar setae (Fig. 2), S. incompleta with slender posterior postsutural intra-alar seta or without it (Fig. 8). The differences present in the structure of male aedeagus (compare Figs 5, 11), cercal plate (compare Figs 6,7 and 12,13) and male sternite 5 (compare Figs 4, 10). 


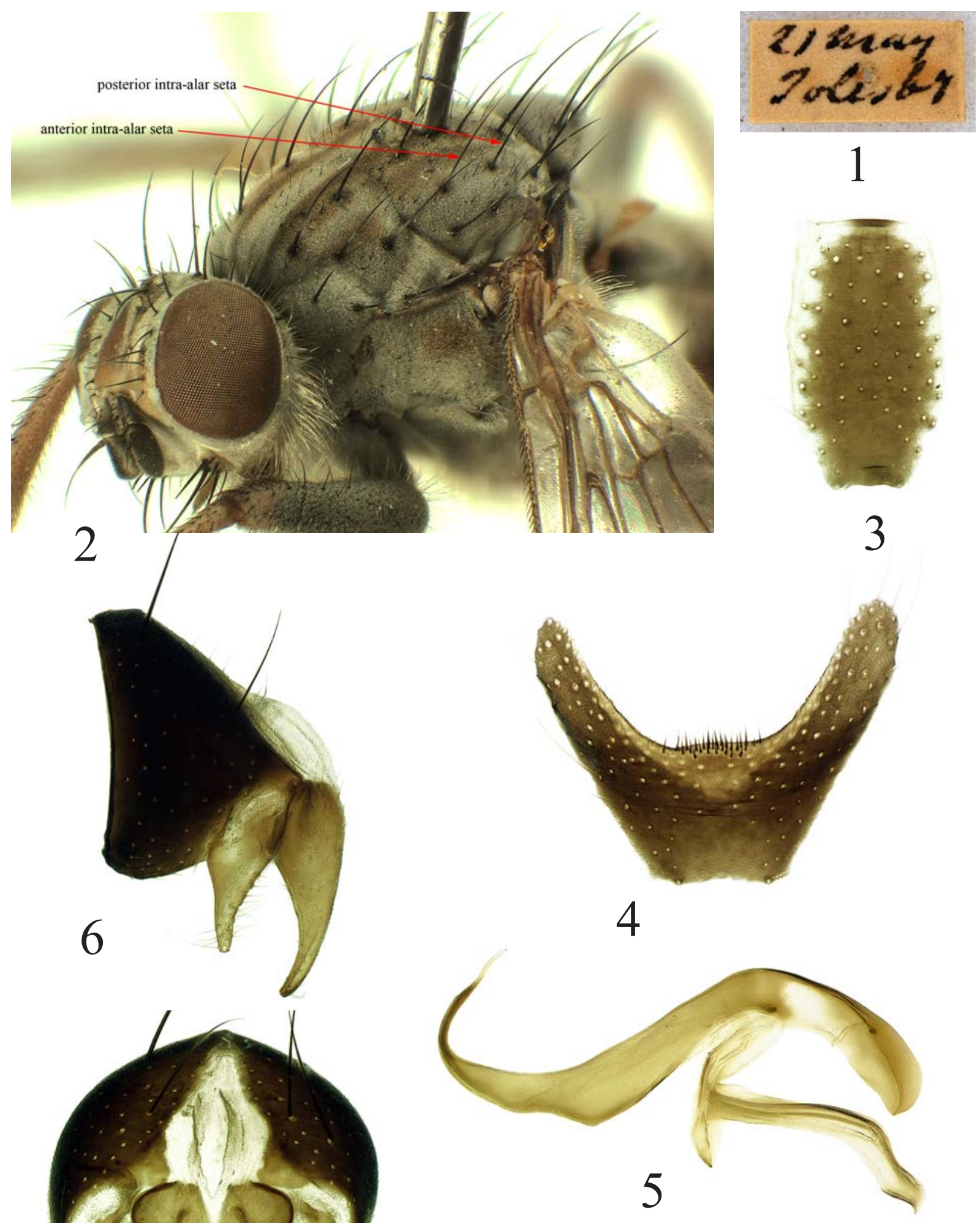

Figs 1-7. Scathophaga decipiens (Haliday), $0^{7}: 1-$ syntype label of $S$. decipiens from NMV (photo by Simon Hinkley); 2 - thorax, lateral view; 3 sternite $4 ; 4$ - sternite $5 ; 5$ - aedeagus, lateral view; 6 - epandrium, cercal plate and surstyli, lateral view; 7 - same, dorsal view.

Pис. 1-7. Scathophaga decipiens (Haliday), OT: 1 - этикетка синтипа $S$. decipiens из NMV (фото Simon Hinkley); 2 - грудь, сбоку; 3 - стернит 4; 4 - стернит 5; 5 - эдеагус, сбоку; 6 - эпандрий, церки и сурстили, сбоку; 7 - то же, сверху. 

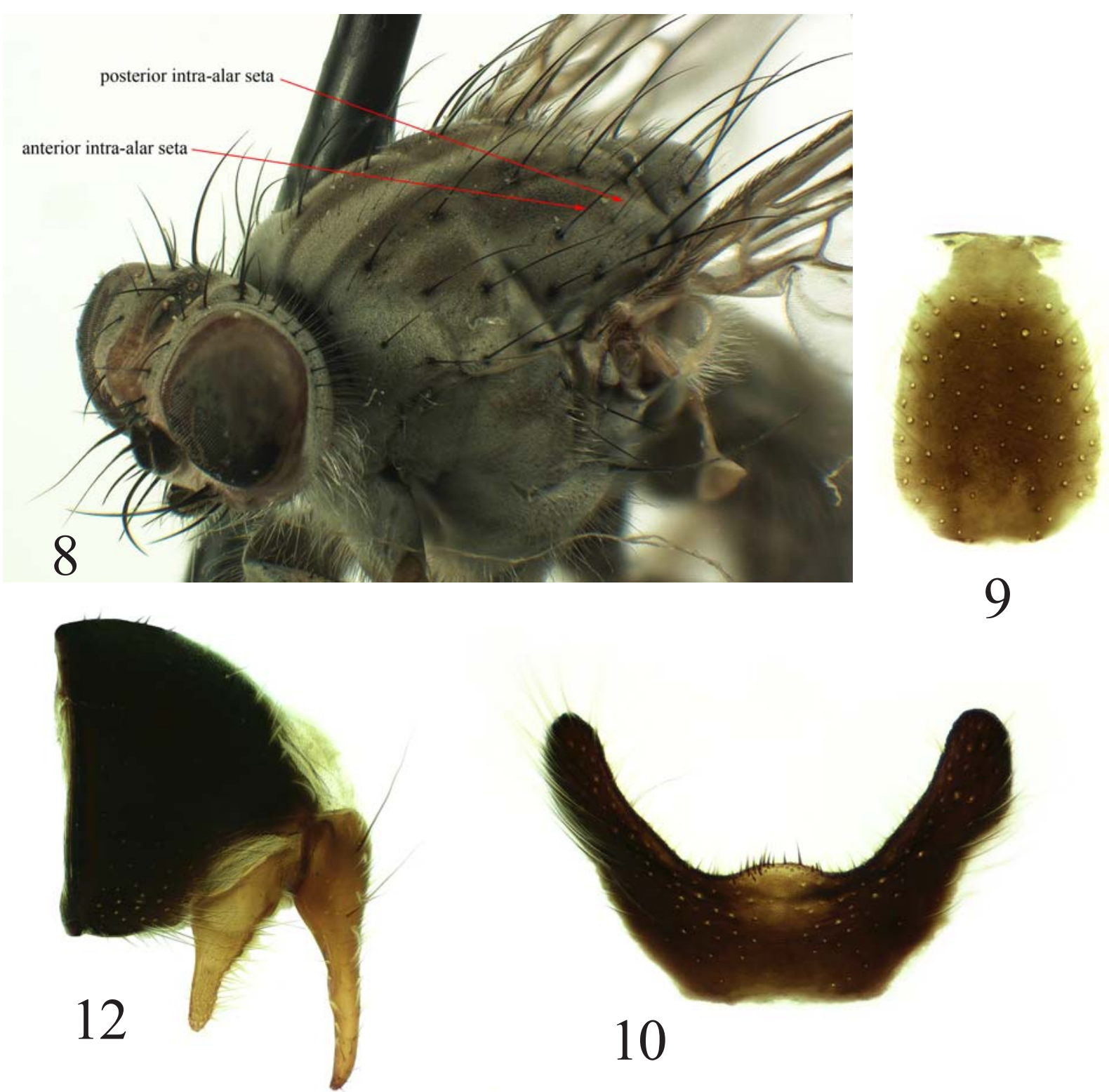

10
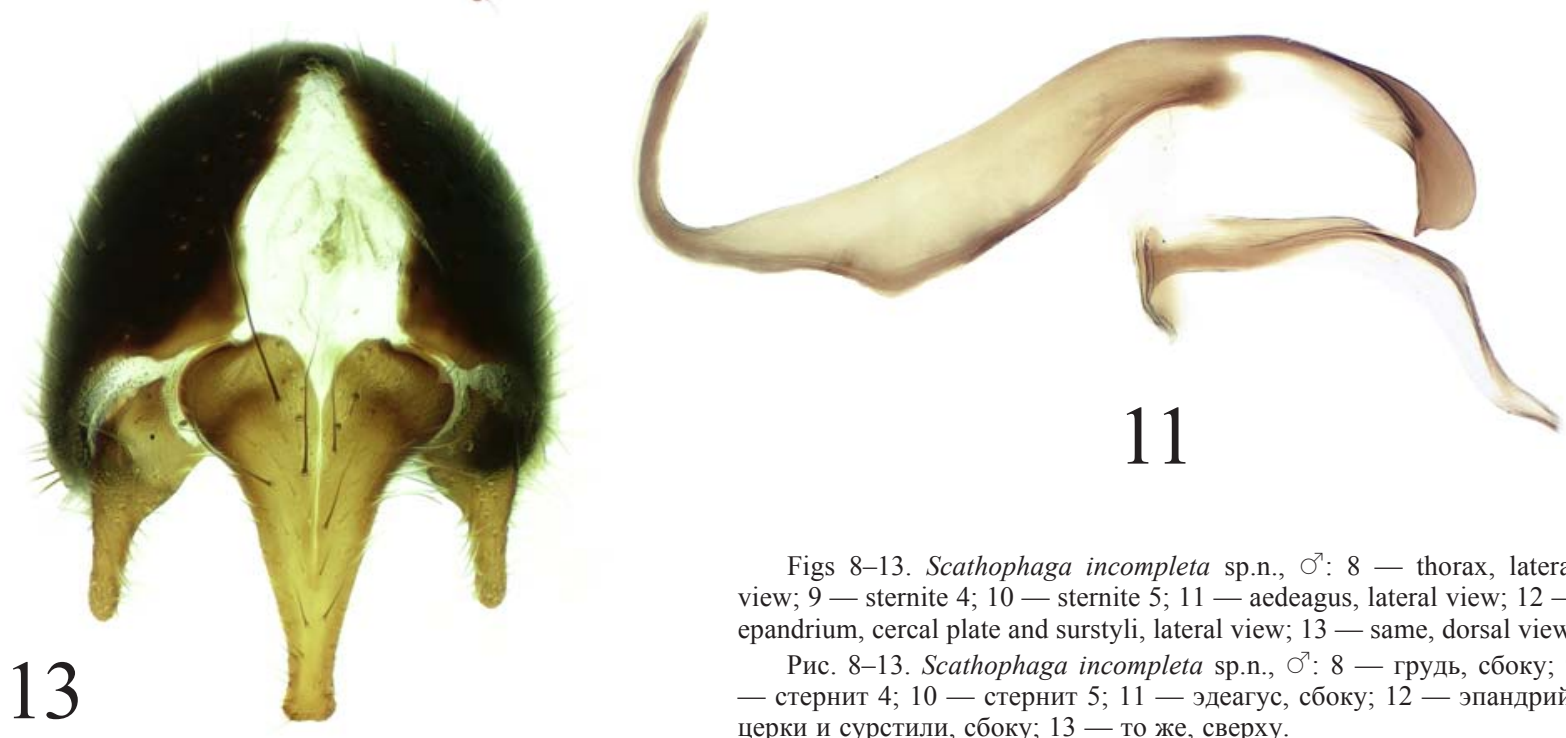

Figs 8-13. Scathophaga incompleta sp.n., $\bigcirc^{7}: 8$ - thorax, lateral view; 9 - sternite $4 ; 10$ - sternite $5 ; 11$ - aedeagus, lateral view; 12 epandrium, cercal plate and surstyli, lateral view; 13 - same, dorsal view. Pис. 8-13. Scathophaga incompleta sp.n., о?: 8 - грудь, сбоку; 9 — стернит 4; 10 - стернит 5; 11 - эдеагус, сбоку; 12 - эпандрий, церки и сурстили, сбоку; 13 - то же, сверху. 
DISTRIBUTION. Azerbaijan, Russia (Adygea, Crimea, Kalmykia).

Acknowledgements. We are very grateful to Dr. Luca Bartolozzi (MZLS) for the loan of male syntype of Scatina fluvialis for study, Dr. Adrian C. Pont (UMO) for the loan of male syntype of Scatina fluvialis and males of Scathophaga decipiens for study, and for great help in labels' decryption, Mr. Simon Hinkley (NMV) for the photo of syntype of Scathophaga decipiens.

The work was conducted within the research project of ZMUM No AAAA-A16-116021660077-3 (A.L. Ozerov) and partly supported by the Program No41 "Biodiversity" (M.G. Krivosheina).

\section{References}

Cumming J.M., Wood D.M. 2009. Adult morphology and terminology // Brown B.V., Borkent A., Cumming J.M., Wood
D.M., Woodley N.E., Zumbado M. (eds.). Manual of Central American Diptera. Vol.1. Ottawa: National Research Council Press. P.9-50.

Curtis J. 1832. British entomology; being illustrations and descriptions of the genera of insects found in Great Britain and Ireland: containing coloured figures from nature of the most rare and beautiful species, and in many instances of the plants upon which they are found. London. Vol.9. P1.386-433 (with text).

McAlpine J.F. 1981. Morphology and terminology-adults // McAlpine J.F., Peterson B.V., Shewell G.E, Teskey H.J., Vokeroth J.R., Wood D.M. (coordinators). Manual of Nearctic Diptera. Vol.2. Ottawa: Research Branch. Agriculture Canada. Monograph 27. P.9-63.

Rondani C. 1867. Scatophaginae Italicae collectae distinctae et in ordinem dispositae. Dipterologiae Italicae prodromus. Pars.VII. Fasc.I. // Atti della Società Italiana di Scienze Naturali. Vol.10. P. 85-135.

Šifner F. 1969. Beiträge zur Kenntiss der fauna Afghanistans (Scatophagidae, Diptera) // Acta Musei Moraviae, Scientiae Naturales. Vol.54. P.293-296.

Stuckenberg B.R. 1999. Antennal evolution in the Brachycera (Diptera), with a reassessment of terminology relating to the flagellum // Studia Dipterologica. Vol.6. P.33-48. 